\author{
Asian Journal of \\ Medical and Biological Research \\ ISSN 2411-4472 (Print) 2412-5571 (Online) \\ www.ebupress.com/journal/ajmbr
}

\title{
Article \\ Smallholder duck farming: a potential source of livelihood in haor women in Bangladesh
}

\author{
Shihan Parvez ${ }^{1}$, M Yousuf Miah ${ }^{1 *}$ and MH Khan ${ }^{2}$ \\ ${ }^{1}$ Department of Poultry Science, Sylhet Agricultural University, Sylhet-3100, Bangladesh \\ ${ }^{2}$ Department of Biochemistry and Chemistry, Sylhet Agricultural University, Sylhet-3100, Bangladesh \\ *Corresponding author: Professor Dr. M Yousuf Miah, Department of Poultry Science, Sylhet Agricultural \\ University, Sylhet-3100, Bangladesh. E-mail: myoumsau2003@gmail.com
}

Received: 21 February 2020/Accepted: 23 March 2020/ Published: 31 March 2020

\begin{abstract}
An experiment was carried out to investigate the effects of feed supplementation on growth performance of Jinding duckling in Haor Household. Nine hundred unsexed day old ducklings were considered for the feeding trial. Duckling were divided into three dietary treatments having 3 replications (50 duckling per replication) and reared on littered floor in an open sided house by providing $0.14 \mathrm{~m}^{2}$ floor space per bird. Dietary treatments Group 0 was considered as control or full scavenging group, fed mash feed to the other group $25 \mathrm{~g}$ and $50 \mathrm{~g}$ per duck per day. Body weight and body weight gain were improved significantly $(\mathrm{p}<0.05)$ with the increasing levels of feed supplementation compared to no feed supplementation group during the period of 4-12 weeks. The average net return of per duckling of $25 \mathrm{~g}$ dietary group was significantly $(\mathrm{p}<0.05)$ higher than that of no supplementation group and $50 \mathrm{~g}$ dietary group throughout the experimental period. Net return per batch were 1924 BDT in $25 \mathrm{~g}$ feed supplementation group at 12 weeks and yearly net profit was 6735 BDT by rearing of 50 ducklings. Benefit-cost ratio was 1:1.30. The result revealed that duck intervention increased duck production, reduce duckling mortality and improved haor women's source of income and significantly contributes to rural livelihoods.
\end{abstract}

Keywords: duckling; feed supplementation; growth; profit; haor

\section{Introduction}

Duck rearing is an integral part of poultry production in Bangladesh. Duck population of Bangladesh is estimated to be 577.52 million (DLS, 2019). The climate and environment of Bangladesh are suitable for duck habitation and the innumerable water bodies are also favorable for duck production. According to a report of Food and Agricultural Organization, the position of Bangladesh with respect to duck meat and egg production is $11^{\text {th }}$ and $4^{\text {th }}$ respectively among the Asian countries (Pingle, 2011). Duck production plays an important role in the haor districts of Bangladesh, providing meat and egg and generates income. Bangladesh is a riverine country where $16488 \mathrm{Km} 2$ are haors, canals, pond and low-lying water reservoir and can be efficiently utilized for duck production. In Bangladesh most of the duck are indigenous (Ahmed, 1986; Arboleda, 1990) but other most important ducks available in the country are Khaki Campbell, Indian Runner, Jinding, Pekin and their crosses. Fluctuations in feed availability from natural sources often affect production costs and vary from $72 \%$ to $87 \%$ of the total production costs (Huque and Sultana, 2002). Reports are also available that scavenging feeds are deficient in nutrients to support optimum growth of ducks (Huque et al., 1994; Biswas et al., 2005). Huque et al. (2001) stated that average feed supplement ( $\mathrm{g} /$ day/bird) is reduced from $105 \mathrm{~g}$ in the dry period (October to December) to $34 \mathrm{~g}$ in the scavenging period (January to September). However, the average egg production increased from $30 \%$ in the dry period to $62 \%$ in the scavenging period. Scavenging ducks are used to forage different types of faunas such as snails, fish, earthworms and flora such as duckweed and algae. All these feeds are rich sources of protein, minerals and vitamins that help meeting different types of nutrient requirements 
needed by ducks and increasing their productivity. Nevertheless, the availability of natural feed resources is affected by their habitats, the waterlogged areas that vary according to seasons of the year and regions of the country. Huque and Sultana (2002) reported that natural water areas in different districts of Bangladesh vary from 151 to 12731 hectares. Total national supply of duck eggs is 73.03 million, 80 percent of which comes from the Haor districts. Hatcheries being the supplier of ducklings play major role in determining the trend of the sub-sector in the commercial market (Oxfam, 2013). It would be possible if they are supported with some feed supplements, vaccine, medicines as well as training. Nutrition has much more effect on production duck being the most important poultry species can contribute to change the economic status and also provide employment to the unemployed youth, rural widow and women of the farmers in these low land areas. The aim of this study was the effect of feed supplementation on growth performance and profitability of ducks in haor smallholders of Sylhet.

\section{Materials and Methods}

The trial was conducted in the farmer's house in haor area with day old ducklings. A survey was conducted in three villages of Haripur, Sylhet district to assess the existing village duck production system. A formal survey schedule was used to collect relevant data, using a multi-stage sampling technique. A total of 20 village households were considered for the study and training was arranged for them. Subsequently an experiment was carried out in order to evaluate effects of feed supplementation to ducklings on growth performance under the haor condition of Sylhet, Bangladesh. Nine hundred day old ducklings were distributed among 18 farmers. Each farmer received 50 birds. For take care of day old ducklings during their early stage of growth without the help of broody hens and there were problems of predators which might cause losses of ducklings, it was decided to rear ducklings for the first three weeks in the confinement in the farmer's house. Thus the distributed ducklings would be more able to adapt under village condition.

Dietary treatments were: Control, $\mathrm{T}_{0}=$ without supplemental feed except those farmers provided under traditional system, $T_{1}=25 \mathrm{~g}$ feed supplementation under scavenging condition, $\mathrm{T}_{2}=50 \mathrm{~g}$ feed supplementation under scavenging condition. Diets were formulated using locally available feedstuffs. Ducklings were initially fed with a standard mash diet containing $2850 \mathrm{kcal} \mathrm{ME} / \mathrm{kg}$ diet (20\% crude protein (CP), as fed) from hatch to 42 days of age. At day 42, these birds were fed diets that contained 17\% CP (as fed) and energy density level (2950 kcal ME/kg diet) (Table 1). The diets were fed until the birds were 84 days of age. The chemical analyses of different feed ingredients were carried out by following standard methods (AOAC, 2004; Kent et al., 1967; Hall and Hacskaylo, 1963). Proximate components, Calcium (Ca) and total Phosphorous (P) of those ingredients were determined in the Animal Nutrition Laboratory, Department of Livestock Services (DLS) and in the Department of Poultry Science, Sylhet Agricultural University. Calcium and total P were determined by atomic absorption and spectrophotometer (FAO, 1989). Amino acids were determined by amino acid analyzer in the Institute of Food Science and Technology of BCSIR Laboratory in Dhaka. The ducklings were immunized against duck plague and duck cholera as per recommendation of the manufacturers.

Records were kept of body weight, feed consumption, mortality, production costs and sale price of live bird. Feed conversion ratio (FCR), net return, cost benefit ratio (BCR) and survivability were calculated. Recorded and calculated data of the diets fed to birds were analyzed by General Linear Model's procedure of SAS (2008) program. Differences among means were determined by the least significant difference (LSD) procedure of SAS (2008).

\section{Results and Discussion}

\subsection{Status of duck farmers}

On the basis of age (years) of the farmers of the study areas were arranged into three main groups namely: young, middle-aged and old. Information exhibited in Table 2 show that most of the farmers $(45 \%)$ in the study territory were middle-aged, young aged were $(35 \%)$ and old aged were $(20 \%)$. Educational qualification was measured by direct interview with the respondent farmers in the study area. Twenty (20\%) percent farmers received primary education and only five $(5 \%)$ percent had higher secondary or above level of education. The literacy rate was twenty five $(25 \%)$ percent. The state of education is very disappointing in Haor areas. According to NIPOR, Sylhet district (which has the largest concentration of Haors) has the lower proportion of people attending the primary and secondary education in compare to other divisions. Thirty five percent of the respondent farmers had larger family size (more than 7 members) which was followed by medium size forty five percent and small size twenty percent of the farmers. The literacy rate of 57 per cent recorded seemed to be lower than that of national average of 64.67 per cent (BBS, 2007) 
The occupation of the participant farmers are shown in Table 2. From the table it is evident that most of respondent farmers (45\%) had agriculture as their main occupation followed by Duck farming (25\%), business $(20 \%)$ and service $(10 \%)$. The participant duck farmers had some subsidiary occupation which helped them in earning some extra income.

According to the number of duck rearing farmer were classified into three categories (small, Medium and large) that shown in Table 2. Seventy (70\%) percent farmer rear below 25 duck, about fifteen (15\%) farmer rear 26100 duck and also fifteen (15\%) farmer rear above 100 duck in this study area. On the basis of land amount farmer also classified into three group 1. landness/small group whose have no land or less than 0.05 acre land 2. medium group whose have between 0.05-2.5 acre land and last one is large group whose have more than 2.5 acre land. From Table 3 about (15\%) farmer were small group, (65\%) farmer were medium group and (20\%) farmer were large group, maximum farmer were medium group in this study area.

Feeding management is the most important factor in duck farming. Because, feed cost is the highest cost among all other production costs. Efficient management in feeding duck saves production cost that increases net return from duck farm. From Table 4 among farmers, 40 percent did not supply additional feed to their ducks. Ducks were reared under scavenging condition (with only natural feed resources) during rainy season, whereas, 60 percent farmers gave supplemental feeding to their ducks to maximize egg production. The main components of supplemental feeds were paddy, a mixture of rice and broken rice and a mixture of rice polish and wheat bran and mixed feed materials. About 55 percent farmers supplemented their ducks with mixed feed whereas $10 \%$, $10 \%$ and $25 \%$ farmers supplemented their ducks with paddy, a mixture of rice and broken rice, a mixture of rice polish and wheat bran.

Table 4 show the average egg consumption per person per year in study area. On the basis of egg consumption farmer are classified into three categories, 1 . Less consumption group who eat less than 50 egg per year about $10 \%$ farmer eat less than 50 egg per year, 2. Medium consumption group (50-100 egg/person/year) about 55\% farmer eat 50-100 egg per year.

High consumption group (above 100 egg/person/year) about 35\% farmer eat above 100 egg per year. Table 4 also show the average duck meat consumption per person per year in study area. On the basis of meat consumption farmer are classified into three categories, 1. low consumption group who eat less than $2 \mathrm{~kg}$ meat per year about $40 \%$ farmer eat less than $2 \mathrm{~kg}$ duck meat per year, 2. medium consumption group $(2-5 \mathrm{~kg}$ meat/person/year) about 55\% farmer eat $2-5 \mathrm{~kg}$ meat per year, 3. high consumption group (above $5 \mathrm{~kg}$ meat/person/year) about $5 \%$ farmer eat above $5 \mathrm{~kg}$ meat per year.

\subsection{Growth performance}

The effects of dietary supplementation on growth performance are shown in Table 5. Day old body weight of different group of duckling had no significant difference among the three dietary groups. Body weight of $4^{\text {th }}$ week had no significant difference among the three dietary groups. Body weight of $12^{\text {th }}$ week was 717,1100 and 1256.66 in $0,25 \mathrm{~g}$ and $50 \mathrm{~g}$ dietary group respectively. The weight was higher in $50 \mathrm{~g}$ feed supplementation group in every stage of weighing compare with other. The body weight of control group was lower among the treated group. There was a significant $(\mathrm{p}<0.05)$ difference between the treated group and control group. The present study was in agreement with the findings of earlier workers (Rahman et al., 2007; Men et al., 1995; Huque and Hossain, 1991; Kamal, 1993; Ketarun, 1998 and Ukil, 1992) who on the basis of their feeding trials reported that increased live weight gain was the result of supplementary feeding in addition to scavenging. But the present findings were contradict with the Chakravarti and Mohan (2014), they found $828 \mathrm{~g}$ body weight at 12 weeks of age in farmer field.

The results showed that differences in body weight gains were statistically significant $(p<0.05)$ among the treatment at 12 weeks. The weekly average body weight gain of $50 \mathrm{~g}$ dietary group was found higher than that of $25 \mathrm{~g}$ dietary group and no supplementation group throughout the experimental period. Huque (1999) found significantly $(\mathrm{P}<0.01)$ higher live weight gain in ducks due to supplementary feeding compared to birds that were reared on scavenging. Normal growth in ducks was highly dependent on nutritional content, especially essential amino acids (Kamran et al., 2008). Other researchers also stated that besides proper nutritional diet, genetics, and management had great influence on the performance and carcass quality of ducks (Adeola, 2006; Xie et al., 2014). Normal growth in poultry is not enough only with limited availability of source materials or energy substrate as a result of the synthesis of proteins (amino acids), but also very influential in the groove in the regulation of growth, protein synthesis by their interaction with growth hormone (Dorup, 2004). 


\subsection{Feed intake}

The results showed that differences in feed intake were statistically significant $(p<0.05)$ among the treatment. The highest feed intake was observed at $12^{\text {th }}$ week for $50 \mathrm{~g}$ dietary group was $3667.48 \mathrm{~g} / \mathrm{b}$, for $25 \mathrm{~g}$ dietary group was $(2266.64 \mathrm{~g} / \mathrm{b})$ and no supplementation group duckling allow to fully scavenging in environment. It was thought that feed consumption to be related to the response of each individual to take advantage of the nutrients, especially protein content in diet. Alleman et al. (2000) and Pesti (2009) stated that each type of poultry had different response to the nutrition, especially protein content and amino acid obtained through diet consumed.

Provision of various levels in the treatment ration was significantly $(\mathrm{P}<0.05)$ affected the FCR. The average FCR of Jinxing ducks under $50 \mathrm{~g}$ dietary group $(2.91)$ was significantly different $(\mathrm{P}<0.05)$ when compared to no supplementation group and $25 \mathrm{~g}$ dietary group treatments. There were decline pattern of FCR with increasing dietary feed supplementation. The lowest FCR was found under $25 \mathrm{~g}$ dietary group treatment (2.06) while the highest was found in $50 \mathrm{~g}$ dietary group (2.91). The results are consistent with the research results of Kamran et al. (2008) who reported that in addition to the role of supplementation in the ration not only served to sustain growth, but also reduced feed consumption and lower FCR. Bons et al. (2002) also noted that the increasing content of feed supplementation decreased FCR of growing Jinding duck. The decrease of FCR due to increasing feed supplement in this study also confirmed by other researchers who claimed that application of feed supplementation in the grower-balanced diet causing low FCR due to the more efficient in forming muscle fibers in the form of meat (Dorup, 2004; Fan et al., 2008). Ketaren (2006) found that FCR of duck fed diets contained pollard at level of 30,40 and 50\% respectively were $3.42 ; 3.39$ and 3.47, while feed intake respectively were 6059,6190 and $6111 \mathrm{~g} /$ bird for ducks raised up to 8 weeks of age.

Survivability percentage of Jinding duck observed in the present study in Table 5. The results showed that differences in Survivability percentage were statistically significant $(\mathrm{p}<0.05)$ among the different treatments. The average Survivability percentage of $50 \mathrm{~g}$ dietary group was found higher than that of $25 \mathrm{~g}$ dietary group and no supplementation group throughout the experimental period. This finding is almost similar with the works of Padhi et al. (2009) and Jalil et al. (1997) they that found average survivability percentage of duck is $82.2 \%$ that were much less in comparison to the present observation which might be due to the fact that in both the later cases, commercial feed were provided throughout the experiment. Hamid et al. (1988) who found that Survivability percentage ranged between 71 to $83 \%$ in three different dietary group. Islam et al. (2016) reported that Survivability percentage of ducks ranged between 95 to $65 \%$ with an average of $80 \%$. Mortality is a serious problem in haor duck production and it needs intervention. Vaccination of flocks is effective but most farmers were unable to vaccinate mainly because of lack of information, skills and high cost of vaccines (Njue et al., 2006). It was noted from the famers that the causes of high mortality in farmer's house ducks under six weeks of age were lack of quality feeds, theft and predators (dogs and eagles). Ducks can be protected from predators by providing shelters and supplementary feeds can be given to ducklings under six weeks of age to improve survivability. It is believed that ducklings older than six weeks might be able to escape attacks from the predators and also successfully search for food. The high costs involved in provision of housing and feeds to ducklings might be challenging in the poverty restricted rural haor communities and it might be necessary but feasible to use locally produced feed resources and building materials.

\subsection{Economic analysis}

Economics of ducklings fed on different level of supplementation are shown in Table 6 . The results showed that differences in average net return were statistically significant $(\mathrm{p}<0.05)$ among the different dietary groups. The highest net return of per duck was observed at $12^{\text {th }}$ week for $25 \mathrm{~g}$ dietary group was 38.49 BDT, no supplementation group was 28.08 BDT and lowest net return was $50 \mathrm{~g}$ dietary group was 16.98 BDT per duck. The average net return of per duckling of $25 \mathrm{~g}$ dietary group was found higher than that of no supplementation group and $50 \mathrm{~g}$ dietary group throughout the experimental period. Net return per batch were 1924 BDT in $25 \mathrm{~g}$ feed supplementation group at 12 weeks and yearly net profit was 6735 BDT by rearing of 50 ducklings. Benefit-cost ratio was 1:1.30. 
Asian J. Med. Biol. Res. 2020, 6 (1)

Table 1. Feed ingredients and nutrient composition of duck diets.

\begin{tabular}{|l|l|l|}
\hline Ingredients (kg) & Duck starter & Duck grower \\
\hline Maize & 48 & 50 \\
\hline Rice Polish & 21.25 & 23.85 \\
\hline Soybean Meal & 25 & 20 \\
\hline Meat and bone meal & 2 & 2 \\
\hline Soybean oil & 0 & 0.5 \\
\hline DCP & 2 & 2 \\
\hline Methionine & 0.22 & 0.2 \\
\hline Lysine & 0.2 & 0.1 \\
\hline Salt & 0.22 & 0.22 \\
\hline Na-Bicarbonate & 0.24 & 0.24 \\
\hline Lime stone & 0.6 & 0.6 \\
\hline Vit. Mineral & 0.25 & 0.25 \\
\hline Phytase & 0.02 & 0.02 \\
\hline Toxin binder & 0.02 & 0.02 \\
\hline Total & 100 & 100 \\
\hline Calculated Nutrients & & \\
\hline ME (Kcal/kg) & 2850 & 2900 \\
\hline CP \% & 20 & 17 \\
\hline CF \% & 6.73 & 6.7 \\
\hline Ca \% & 1.08 & 1.04 \\
\hline P \% & 0.62 & 0.60 \\
\hline Lysine \% & 1.13 & 0.88 \\
\hline Methionine \% & 0.51 & 0.45 \\
\hline & & \\
\hline & & \\
\hline
\end{tabular}

Table 2. Status of duck farmers in Haripur village.

\begin{tabular}{|c|c|c|}
\hline Parameters & Category & Farmers (\%) \\
\hline \multirow[t]{3}{*}{ Age (year) of the farmers } & Young $(<35$ years $)$ & 35 \\
\hline & Middle-Aged (36-50) & 45 \\
\hline & Old (> 50 years) & 20 \\
\hline \multirow[t]{5}{*}{ Level of Education } & Illiterate & 25 \\
\hline & Can sign only & 30 \\
\hline & Primary & 20 \\
\hline & Secondary & 20 \\
\hline & HSC or above & 5 \\
\hline \multirow[t]{3}{*}{ Family Size of the farmers } & Small (up to 4) & 20 \\
\hline & Medium (5-6) & 45 \\
\hline & Large (> 6 members) & 35 \\
\hline \multirow{4}{*}{ Occupation of duck farmers } & Duck farming & 25 \\
\hline & Agriculture Service & 45 \\
\hline & Business & 20 \\
\hline & Service & 10 \\
\hline \multirow[t]{3}{*}{ Number of duck rearing of the farmer } & Small $(<25$ duck $)$ & 70 \\
\hline & Medium (26-100 duck) & 15 \\
\hline & Large (> 100 duck) & 15 \\
\hline \multirow[t]{3}{*}{ Amount of the land of farmer } & Small/Landless $(<0.05$ acre $)$ & 15 \\
\hline & Medium (0.051-2.5 acre) & 65 \\
\hline & Large (> 2.51 acre) & 20 \\
\hline
\end{tabular}


Table 3. Duck feeding and management practices by duck farmers in Haripur village, Sylhet.

\begin{tabular}{|l|l|l|}
\hline Parameters & Category & Farmers (\%) \\
\hline \multirow{2}{*}{ Duck feed Source } & Only Scavenging & 40 \\
\cline { 2 - 3 } & Scavenging and supplementation & 60 \\
\hline \multirow{4}{*}{ Fmount of feed } & Adequate & 35 \\
\cline { 2 - 3 } & Inadequate & 65 \\
\hline \multirow{5}{*}{ Feed ingredients used for ducks } & Paddy & 10 \\
\cline { 2 - 3 } & Rice and broken rice & 10 \\
\cline { 2 - 3 } & Rice polish and wheat bran & 25 \\
\cline { 2 - 3 } & Mixed feed & 55 \\
\hline
\end{tabular}

Table 4. Farmer categories on the basis of egg and meat consumption per person per year.

\begin{tabular}{|l|l|l|}
\hline Parameters & Category & Farmers $(\%)$ \\
\hline \multirow{3}{*}{ Egg consumption/person/year } & Low consumption $(<50 \mathrm{egg})$ & 10 \\
\cline { 2 - 3 } & Medium consumption $(51-100)$ & 55 \\
\cline { 2 - 3 } & High consumption $(>100 \mathrm{egg})$ & 35 \\
\hline \multirow{2}{*}{$\begin{array}{l}\text { Meat consumption } \\
(\mathrm{Kg}) / \text { person/year }\end{array}$} & Low consumption $(<2 \mathrm{~kg})$ & 40 \\
\cline { 2 - 3 } & Medium consumption $(2-5 \mathrm{~kg})$ & 55 \\
\cline { 2 - 3 } & High consumption $(>5 \mathrm{~kg})$ & 5 \\
\hline
\end{tabular}

Table 5. Growth performance of duck fed on different levels of feed supplementation at 12 weeks of age.

\begin{tabular}{|l|l|l|l|l|}
\hline \multirow{2}{*}{ Parameters } & \multicolumn{2}{|c|}{ Level of feed supplementation $(\mathbf{g})$} & $\begin{array}{l}\text { Level of } \\
\text { significance }\end{array}$ \\
\cline { 2 - 5 } & $\mathbf{0}$ & $\mathbf{2 5}$ & $\mathbf{5 0}$ & NS \\
\hline Day old body wt $(\mathrm{g} / \mathrm{b})$ & $35.87 \pm 0.29$ & $36.15 \pm .19$ & $35.96 \pm .20$ & NS \\
\hline 4th week body wt $(\mathrm{g} / \mathrm{b})$ & $548.33 \pm 33$ & $550 \pm 2.88$ & $557.5 \pm 3.81$ & $*$ \\
\hline 12th week body $(\mathrm{g} / \mathrm{b})$ & $717 \mathrm{c} \pm 2.14$ & $1100 \mathrm{~b} \pm 5.77$ & $1256.66 \mathrm{a} \pm 3.81$ & $*$ \\
\hline Body weight gain $(\mathrm{g} / \mathrm{b} / \mathrm{d})$ & $8.13 \mathrm{c} \pm .02$ & $12.69 \mathrm{~b} \pm .07$ & $14.55 \mathrm{a} \pm .04$ & $*$ \\
\hline Feed intake $(\mathrm{g} / \mathrm{b})$ & - & $2266.64 \pm 6.78$ & $3667.48 \pm 7.92$ & $*$ \\
\hline FCR & - & $2.06 \pm .01$ & $2.91 \pm .01$ & $*$ \\
\hline Survivability\% & $84.66 \mathrm{c} \pm .21$ & $88.27 \mathrm{~b} \pm 0.40$ & $89.83 \mathrm{a} \pm 0.47$ & $*$ \\
\hline
\end{tabular}

$0=$ only scavenging, $25 \mathrm{~g}=$ Scavenging $+25 \mathrm{~g}$ feed supplementation, $50 \mathrm{~g}=$ Scavenging $+50 \mathrm{~g}$ feed supplementation,

$\mathrm{NS}=$ No significance, $*=0.05 \%$ significance. $\mathrm{FCR}=$ Feed conversation ratio

Table 6. Economics of ducklings fed on different level of supplementation.

\begin{tabular}{|l|l|l|l|l|}
\hline \multirow{2}{*}{$\begin{array}{l}\text { Parameters } \\
\text { BDT) }\end{array}$} & \multicolumn{1}{|c|}{ Level of feed supplementation $(\mathbf{g})$} & \multicolumn{1}{c|}{ Level of significance } \\
\cline { 2 - 5 } & \multicolumn{1}{|c|}{$\mathbf{0 5}$} & \multicolumn{1}{|c|}{$\mathbf{5 0}$} & \\
\hline Total cost & $79.34^{\mathrm{c}} \pm 0.30$ & $126.87^{\mathrm{b}} \pm .65$ & $171.15^{\mathrm{a}} \pm .96$ & $*$ \\
\hline Gross Return & $107.62^{\mathrm{c}} \pm .32$ & $165.00^{\mathrm{b}} \pm 0.86$ & $188.50^{\mathrm{a}} \pm 0.57$ & $*$ \\
\hline Net return/duck & $28.08^{\mathrm{b}} \pm 0.16$ & $38.49^{\mathrm{a}} \pm 0.67$ & $16.98^{\mathrm{c}} \pm 1.38$ & $*$ \\
\hline Net return /batch & 1420.5 & 1924.5 & 849 & $*$ \\
\hline BCR & $1.35 \mathrm{a} \pm 0.004$ & $1.30 \mathrm{~b} \pm 0.010$ & $1.10 \mathrm{c} \pm 0.008$ & $*$ \\
\hline
\end{tabular}

$0=$ only scavenging, $25 \mathrm{~g}=$ Scavenging $+25 \mathrm{~g}$ feed supplementation, $50 \mathrm{~g}=$ Scavenging $+50 \mathrm{~g}$ feed supplementation, $\mathrm{NS}=$ No significance, $*=0.05 \%$ significance. FCR $=$ Feed conversation ratio

\section{Conclusions}

The current study reveals that duck farming significantly contribute to farmer livelihoods in terms of nutrition and income. Based on the findings of this study, it is fair enough to note that duck rearing is a profitable business in the study area. Promotion of this enterprise would largely enhance the process of employment generation, income potentiality and poverty reduction which are now considered as the major concern in the development planning process of Bangladesh. The farmers made a profitable use of improved breed of Jinding duck. From growth performance and economic cost analysis on this experiment we found that if we supplied 25 $\mathrm{g}$ feed supplementation per day with scavenging of duck, farmers were economically more benefited than the 
other dietary groups. The result revealed that duck interventions improved haor women's source of income and significantly contributes to rural livelihoods.

\section{Acknowledgements}

The authors gratefully acknowledge the Ministry of Education, Govt. of the People's Republic of Bangladesh for financing this project.

\section{Conflict of interest}

None to declare.

\section{References}

Ahmed S and N Islam, 1986. Backyard Poultry Development Project in 100 villages, sponsored by Bang. Agril. Univ., Mymensingh and assisted by UNICEF, Bangladesh. Proc. 1st Con. Bang. Anim. Husbandry Assoc., Bang. Agri. Res. Council, Dhaka. P. 133-138.

Adeola O, 2006. Review of research in duck nutrient utilization. Int. J. Poult. Sci., 5: 201-204.

Alleman F, J Michel, M Chagneau and B Leclercq, 2000. The effect of dietary protein independent of essensial amino acids on growth and body composition in genetically lean and fat chickens. Br. Poult. Sci., 41: 214218.

Arboleda CR, 1990. Development of Duck Industry in Bangladesh. A discussion paper presented to selected government officers, at the Department of Livestock Services, Pashu Sampad Bhaban, Dhaka, October 30.

AOAC, 2004. Official Methods of Analysis. Association of the Official Agricultural Chemists. Washington, D.C. 1-34.

Biswas MSA, SD Chowdhury, MG Mustafa and J Bell, 2005. Availability and nutrient of scavengable feed resources and crop and gizzard contents of scavenging ducks in Bangladesh. Proceedings of the Fourth International Poultry Show and Seminar, World's Poultry Science Association, Bangladesh Branch, pp. 167172.

Bons A, R Timmler and H Jeroch, 2002. Lysine requirement of growing ducks. Br. Poult. Sci., 43: 677-686.

FAO, 1989. Production Year Book. Food and Agricultural Organization, 50: 216-219.

Chakravathi PV and B Mohan, 2014. Comparison of performance of Khaki Campbell Ducks under organized farm and field conditions. Shanlax International Journal of Veterinary Science, 2: 1-3.

DLS, 2019. Annual Progress Report. Department of Livestock Services., Farm gate, Dhaka.

Dorup I, 2004. The impact of minerals and micronutrients on growth control. In: te Pas, MFW, Everts ME, Haagsman HP, editors. Muscle development of livestock animal's physiology, genetics and meat quality. Oxford (UK): CABI Publishing, CAB International Wallingford Oxfordshie OX10 8 DE. p. 125-136.

Fulbert AC, Ngokaka and P Mompoundza, 2009. Productivity of Khaki Campbell Ducks under the Local Agricultural Produce and by Products in the Breeding Conditions of Brazzaville- Congo. Pak. J. Nutr., 8: 1910-1914.

Hamid MA, SMRK Chowdhary and SD Choudhury, 1988. A comparative study on the performances of growing ducklings Khaki Campbell, Indian Runner and Indigenous ducks under farm conditions. Indian journal of Poultry Science, 23: 118-121.

Huque KS and N Sultana, 2002. Study on the existing duck production systems in Bangladesh. A report of Bangladesh Livestock Research Institute, Bangladesh.

Huque KS, MSK Sarker, QME Huque and MN Islam, 2001. Duck production in the Sylhet basin of Bangladesh prospects and problems. Proceeding of WPSA. $2^{\text {nd }}$ International poultry show and seminar, February 16-17: 40-51.

Huque QME and MJ Hossain, 1991. Production potentiality of ducks of three genotypes under scavenging system of management. Bang. J. Anim. Sci., 20: 119-122.

Huque QME, 1999. Nutritional Status of family poultry in Bangladesh. Livestock Research for Rural Development, (II) 3. http:// www.cipav.org.co/Irrd/Irrd 11/3/hup113.htm

Huque QME, MA Ukil and MJ Hossain, 1993. Supplementary feeding for laying ducks under scavenging condition. Bangladesh Journal of Livestock Research, 1: 57-62.

Hall WC and J Hackskaylo, 1963. Methods and Procedure for Plant Biochemical and Physical Research. The Exchange Store, College Station, Texas. pp. 9-16.

Islam MA, MAR Howlider, MA Alam, MA Heyamet and M Debnath, 2016. Present status, problem and prospect of duck farming in rural areas of Mymensingh district, Bangladesh. Asian J. Med. Biol. Res., 2: 202- 212 . 
Jalil MA, A Ali, J Begum and MR Islam, 1997. Study on the performance of different genotypes of ducks under village condition. Asian-Australas. J. Anim. Sci., 10: 192-195.

Kamal MM, 1993. Study on the effect of supplementation of rice polish on the performance of Khaki Campbell Duck under village condition. M. Sc. Thesis. Department of Animal Nutrition, Bang. Agril. Univ., Mymensingh, Bangladesh.

Ketaren PP, 1988. Feed and feeding of duck in Indonesia. Indonesia Agriculture Research Development Journal, 20: 51-56.

Kent Jones DW and AJ Amos, 1967. Modern Cereal Chemistry, $6^{\text {th }}$ edn. Food Trade Press LTD. pp. 563-564.

Men BX, B Ogle and TR Preston, 1995. Studies on duck production in the Mekong, Delta, Vietnam. Integrated farming in human development. Proceeding of a workshop, Can Tho University, Vietnam.

Njue SW, JL Kasiiti and SG Gacheru, 2006. Assessing the economic impact of commercial poultry feeds supplementation and vaccination against Newcastle disease in local Chicken in Kenya. Proceedings of a final research coordination meeting organized by the Joint FAO/ International Atomic Energy Agency (IAEA) held in Vienna, 24-28 May 2004.

Oxfam, 2013. Report on Duck Value Chain in Coastal and Haor areas in Bangladesh.

Padhi MK, BK Panda and SK Sahoo, 2009. Comparative performance of Khaki Campbell, Desi ducks and their crossbreeds. Indian Vet. J., 86: 942-945.

Pesti GM, 2009. Impact if dietary amino acids and crude protein levels in broiler feeds on biological performance. J. Appl. Poult. Res., 18: 477-486.

Pingel H, 2011. Waterfowl Production for Food Security. Lehman Information, 46, 34- 37.

Rahman MM, MJ Khan and M Shahjalal, 2007. Effect of different supplemental diets on growth and egg production of Jinding ducks under scavenging condition. Proceedings of $5^{\text {th }}$ International Poultry Show and Seminar, World's Poultry Science Association, Bangladesh Branch, March 1-3, pp. 212-220.

SAS, 2008. Statistical Analysis Systems. SAS User's Guide: Version 9.2, 2nd edition. SAS Inst. Inc. USA.

Ukil MA, 1992. Availability of nutrients of scavenging chickens and duck in Bangladesh. M.Sc. Thesis Department of Poultry Science, Bangladesh Agricultural University, Mymensingh, Bangladesh.

Xie M, JN Zhao, SS Hou and W Huang. 2010 The apparent metabolizable energy requirement of White Pekin ducklings from hatch to 3 weeks of age. Animal Feed Science and Technology, 157: 95-98. 